\title{
Luther Burbank: Plant Breeding Artist, Horticulturist, and Legend
}

\author{
Jules Janick ${ }^{1}$ \\ Department of Horticulture \& Landscape Architecture, Purdue University, 625 Agriculture Mall Drive, \\ West Lafayette, IN 47907
}

Additional index words. California, history, Santa Rosa

\begin{abstract}
Luther Burbank (1849-1926), the best-known horticulturist in the United States, was honored in 1940 by having a U.S. postage stamp in his honor-as a scientist! Burbank became a legend in his time as the plant inventor and horticultural wizard releasing a prodigious 800 new cultivars, a number of which are still being grown, the most famous being the 'Burbank' potato, the 'Santa Rosa' plum, and the 'Shasta' daisy. During his lifetime he was considered as a coequal with Henry Ford, inventor of the assembly line factory, and Thomas A. Edison, inventor of the light bulb and phonograph. Hugo de Vries, Liberty Hyde Bailey, and Nikolai Ivanovich Vavilov visited him and lauded his operation. Burbank promoted the concept that plant breeding could be the basis of a business and his headquarters in Santa Rosa, CA, became world famous. He established a publication company to disseminate his work and was instrumental in the eventual passage of the Plant Patent Act of 1930. However, Burbank was not a scientist. Although a strong supporter of Darwin and the theory of natural selection, he did not understand the contributions of Mendel to genetics and breeding. He performed no experiments in the classical sense and his notes were fragmentary. In 1904, he received a large grant from the Carnegie Institution (\$10,000 annually) to promote the scientific study of plant breeding, which was discontinued after 5 years when the reviewer, George Harrison Shull, determined that Burbank's procedure was more art than science. However, Burbank is justly famous as a successful plant breeder. He intuitively followed the modern rationale of plant breeding by obtaining abundant diversity, using repeated and successive hybridization, and carrying out rigorous selection. Above all he had an eye and feel for plants. His success is an affirmation that plant breeding is an art as well as a science. As an innovative plant breeding artist, Luther Burbank remains an inspiration to plant breeders and horticulturists.
\end{abstract}

Luther Burbank still remains the best known horticulturist in the United States and has become a legend as a plant wizard and inventor of plants. In 1940 he appeared on the U.S. postage stamp (Fig. 1) in the Famous Americans series along with John James Audubon (ornithologist and painter), Crawford W. Long (physician and anesthesiologist), Walter Reed (physician and epidemiologist), and Jane Addams (sociologist and reformer). Through his innumerable plant creations (over 800 releases), he became known as a plant breeder extraordinaire, and in his lifetime, he was thought of as the "high priest of horticulture" and the "plant wizard." His charming personality endeared him to the public. Burbank appears in paintings by Frida Kahlo and Diego Riviera and he was lionized in the popular press in innumerable articles. After his death, rights to his plant material were sold to Stark Brothers' Nursery, which sold the vegetables and seed rights to Burpee Seed Company in 1931, where Burbank's creations continued to be promoted to the public. In 1991 he was elected to the ASHS Hall of Fame and the Luther Burbank Home and Gardens was honored as an ASHS Horticultural Landmark in 2003. His life and career have been the subject of books and articles in the popular

Received for publication 15 July 2014. Accepted for publication 8 Aug. 2014.

This paper was part of the workshop "Contributions of Luther Burbank: Plant Breeding Artist and Legend" held 22 July 2013 at the ASHS Conference, Palm Desert, CA, and sponsored by the ASHS History of Horticultural Science Working Group.

${ }^{1}$ To whom reprint requests should be addressed; e-mail janick@purdue.edu. and scientific press including works by Peter Dreyer (1993), Walter Howard (1945, 1945-46), Jane S. Smith (2009), and Henry Smith Williams (1915), Williams et al. (1915). His position as a scientist has been critically reviewed by James Crow (2001) and Donald F. Jones (1937).

Luther Burbank (Fig. 2) remains a horticultural enigma and this brief review of his life is an attempt to put his contributions to horticulture and plant breeding into perspective. A retrospective review of his accomplishments is the goal of this workshop. It includes papers entitled "Russet Burbank: No Ordinary Potato" by Charles R. Brown; "A Vast Array of Beauty: The Accomplishments of Luther Burbank, the Father of American Ornamental Plant Breeding," by

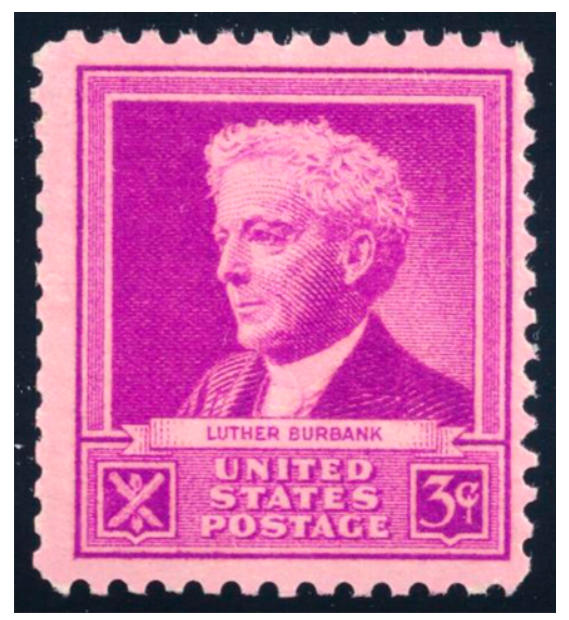

Fig. 1. Luther Burbank portrait in a 1940 U.S. postage stamp, one of five scientists of the Famous Americans series. Burbank is the only U.S. horticulturist so honored.
Neil O. Anderson and Richard T. Olsen; "Luther Burbank's Plums" by David A. Karp; " $21^{\text {st }}$ Century Approach to Improving Burbank's 'Stoneless' Plum" by Ann Callahan, Chris Dardick, and Ralph Scorza; "Luther Burbank's Contributions to Walnuts" by John Preece and Gale H. McGranahan; and "Luther Burbank's Berries" by Kim E. Hummer, Chad E. Finn, and Michael Dossett. These papers make clear that Luther Burbank is justly famous as an extraordinarily successful plant breeder. He intuitively followed the modern rationale of plant breeding by obtaining abundant diversity, using repeated and successive hybridization, and carrying out rigorous selection. He cannot be considered a scientist in the modern sense, but he was clearly a plant breeding artist for above all he had an eye and feel for plants. His success is an affirmation that plant breeding is as much an art as a science. As an innovative plant breeding artist, Luther Burbank remains an inspiration to plant breeders and horticulturists.

Early years. Luther was born in Lancaster, MA, on 7 Mar. 1849, a son of Samuel Burbank, owner of a small brick factory, and his third wife, Olive Burpee Ross. Young Luther was educated at the Lancaster Academy. In the early 1870 s, he obtained Darwin's Variation of Animals and Plants under Domestication (published in the United States in 1869) from the local library and Burbank would later claim that it opened up a new world for him to create new plant varieties. At the same time he became interested in horticulture based on a book, Gardening for Profit, in the Market and Family Garden by Peter Henderson. In 1871 he purchased 17 acres of farmland in nearby Lunenburg where he planned to raise 
vegetables for sale, but he did not lose sight of his larger ambitions to accelerate evolutionary changes by human intervention.

In 1872 , he noticed a seedpod on a planting of 'Early Rose' potato, a white-fleshed variant of 'Garnet Chili' imported from somewhere in South America that had some resistance to late blight caused by Phytophthora infestans. He harvested 23 seeds and the rest is history. The seedlings produced variable populations but two had large tubers, and one (\# 15) proved to be high-yielding (3 pounds from one plant) with smooth skin, good taste, and long storage. In 1874 he sold rights to the potato to J.H. Gregory (the seedsman who named the 'Hubbard' squash from an introduction grown in Marblehead, MA) for $\$ 150$ (Burbank had asked for $\$ 500$ ). More important was that Gregory agreed to name the potato 'Burbank'. A subsequent
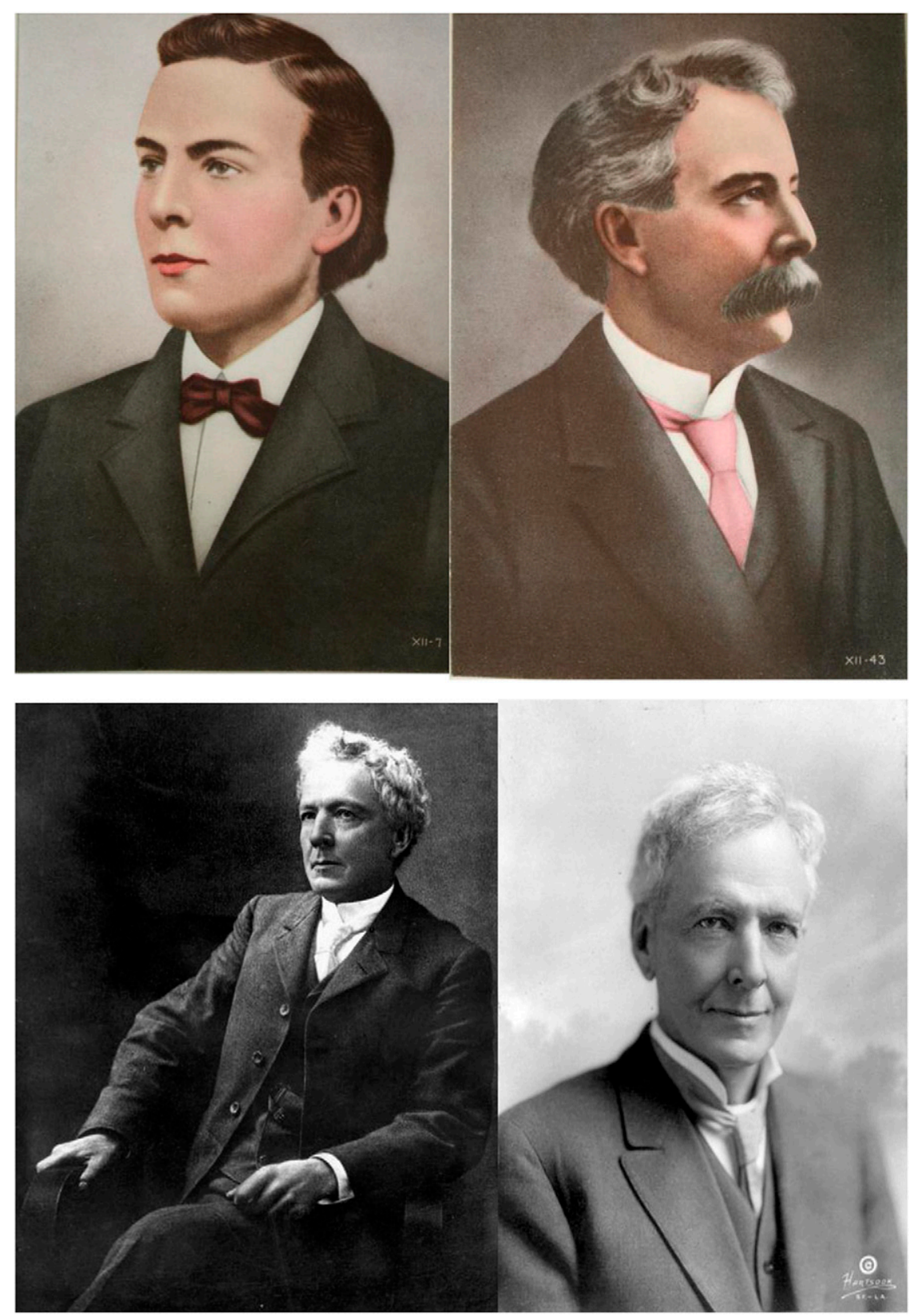

Fig. 2. Photographs of Luther Burbank.

mutation became the 'Russet Burbank', the most famous potato in U.S. history, the source of McDonald's fries and the baked potato that adorns our steaks.

Move to California. In 1875, the 26-year-old Burbank left the rocky soil of Massachusetts to join his brothers in California. He sold his Lunenburg farm and traveled to Santa Rosa 60 miles north of San Francisco with the expressed aim of repeating his success in plant improvement achieved with the potato. It was a fateful decision that would change his life. It was not easy. Supplemented by his skill at carpentry, Burbank went into a small nursery business. Using some land of his mother, who also immigrated to Santa Rosa, Luther started a small nursery based on his improved hybridized material. In 1880, he printed his first catalog, but his annual returns barely were greater than he would have achieved as a carpenter. However, in 1881 he entered a new direction. Catering to the demand for the burgeoning fruit industry of California, he took a daring challenge to fulfill an order of 20,000 trees of the newly introduced 'Agen' plum for drying. Burbank proved to be a skilled horticulturist. He produced nursery trees in a single year by germinating almond seedlings in the field, inserted buds of 'Agen' into the growing shoots, and fulfilled the order in 9 months, an amazing feat. Burbank nurseries prospered and by 1894 Burbank's advertisements proclaimed a stock of 500,000 fruit and nut trees (Fig. 3). At the same time he continued his hybridizations on an increasingly larger scale. His modus operandi was to make extensive crosses, with few notes that only Burbank could decipher. His nursery operation expanded to nearby Sebastapol. Seeds and plant materials such as plums from Japan were imported. $\mathrm{He}$ introduced the fruiting nursery and grafted seedlings to mature plants to reduce juvenility. He had assistants but carried out all selection personally. In 1888 he sold his nursery to concentrate on his passion, producing new plants and plant forms (Fig. 4). At the age of 40 years, Burbank proved himself a successful nurseryman and entrepreneur and he spent a year traveling, collecting seed.

Spurred by a change on postal rates, Burbank entered the mail order nursery business based on his own catalog of horticultural wonders. Bolstered by exuberant promotion and a wide assortment of plants, a new business plan was developed. Burbank's market was not the general public, but rather other nurserymen. He offered his creations at very high prices (from $\$ 250$ to $\$ 3000$

\section{SANTA ROSA NURSERIES!

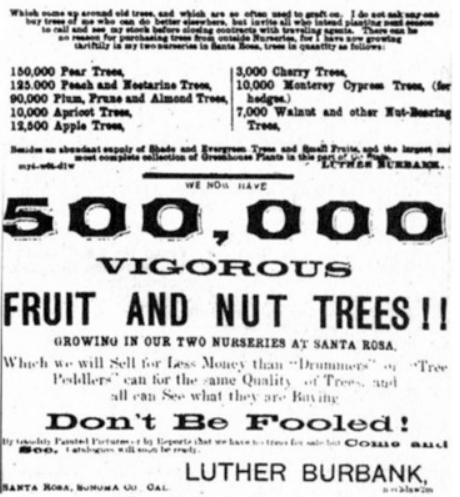

Advertisement, Santa Rosa Nurseries, 1884 . Courtesy luther Burbank Home \& Gardens. Santa Rosa, California

Fig. 3. Advertisement of the Santa Rosa Nurseries, 1884.

HortScience Vol. 50(2) February 2015 
and more) on an exclusive basis, the buyer acquiring all stock and rights. He in a sense initiated the business of marketing selections and germplasm derived from plant breeding. His annual catalogs over the next 20 years are a testament to his abilities as a breeder and his skill as a promoter. There were many outstanding releases (Table 1). Backed by the results of his breeding and selection success as well as self-promotion, Burbank created his public image as the plant wizard. However, Burbank was not an imposter for he delivered remarkable new innovations.

Burbank promoted his personal brand. Soon the name Luther Burbank added to a selection increased its commercial value. A series of newspaper and magazine articles and testimonies promoted his skill and his business as a creator of scientific and horticultural marvels. He played the press as a violin. He had his critics, but the truth was that he delivered. He had very successful commercial dealings with John Lewis Childs, a successful nurseryman, Stark Brothers' Nurseries, and Burpee Seeds (Washington

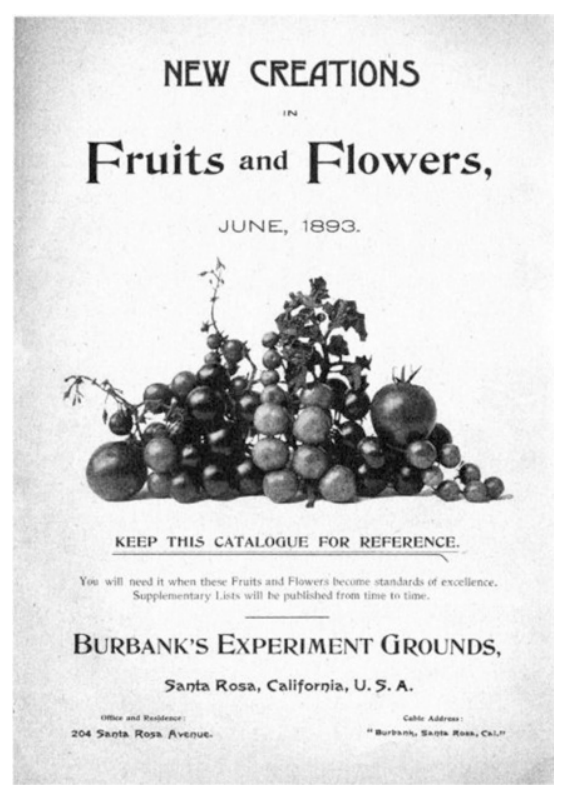

Fig. 4. Advertisement of New Creations of Fruits and Flowers from Burbank's Experimental Grounds, Santa Rosa, 1893.
Atlee Burpee was a distant cousin). Most impressive were the great diversity of species that Burbank improved.

Plant wizard and legend. By the turn of the century, interest in Burbank was so high that he became a magnet for a stream of distinguished personalities who toured his operation in Santa Rosa (Fig. 5). His pleasant personality endeared him to many visitors including Helen Keller, Jack London, and the King of Belgium as well as the scientists including Hugo de Vries, Liberty Hyde Bailey, and Nikolai Ivanovich Vavilov. All were charmed with what they saw and were duly impressed by the enormous variety of plants under development and the wealth of diversity in his nursery garden. He created a stir in the academic community. In 1904, David Starr Jordan, the president of Sanford University, invited Burbank to join the faculty as a lecturer on evolution. Burbank described inheritance as an intricate web of vibrations and magnetic forces, but the lantern slides of his creations impressed everyone. Finally his supporters succeeded in getting him an enormous grant from the Carnegie Institution of $\$ 10,000$ a year but with the stipulation that a trained biologist was to prepare a report on his work. The observer chosen was George Harrison Shull, an eminent biologist who was to become famous in plant breeding through his studies on inbreeding and outbreeding of maize that led directly to hybrid corn. Although Shull admired Burbank's accomplishments, he was not impressed with Burbank as a scientist and accurately attributed his success to his abilities as a selector. Burbank was not about to record his methods or achievements in scientific journals but chose rather to embark on a publishing venture that led to a 12 -volume work of his creations (Fig. 6). It soon became clear that his methods were best explained by his results. Oddly enough his major scientific contribution, that it was possible to create new hybrids that were essentially a new true breeding species (allopolyploids), was rejected by Hugo de Vries. His new achievement, the 'Sunberry' (relabeled the 'Wonderberry'), derived from a cross of two nightshade species was derided (today it is coming back). His plumcots were not accepted as true hybrids but today they are. His funding from the Carnegie Institution was discontinued in 1909 Burbank was in large part responsible for the enactment of the Townsend-Purnell Plant Patent Act of 1930. In committee, Congressman Purnell read a letter of Burbank despairing over his ability to be rewarded from his discoveries:

"A man can patent a mousetrap or copyright a nasty song, but if he gives to the world a new fruit that will add millions to the value of earth's annual harvests, he will be fortunate if he is rewarded by so much as having his name connected with the result."

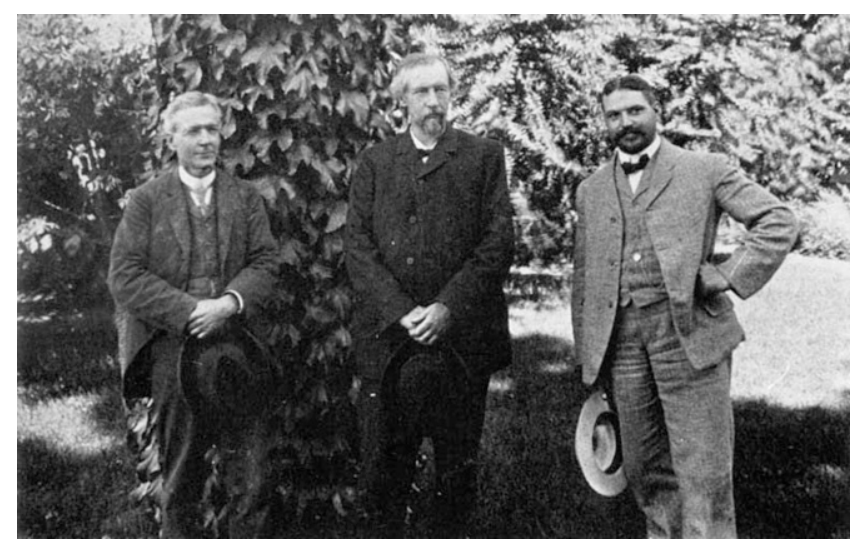

Fig. 5. Luther Burbank, Hugo de Vries, and George Harrison Shull, 1907.

Table 1. Some of the better known creations of Luther Burbank from his 800 releases and their issue dates. ${ }^{2}$

\begin{tabular}{|c|c|c|c|c|c|}
\hline Burbank potato & 1873 & Miracle (stoneless) plum & 1901 & Black Giant cherry & 1911 \\
\hline Himalaya blackberry & 1885 & Shasta daily & 1901 & Rainbow corn & 1911 \\
\hline Satsuma plum & 1886 & Burbank cherry & 1903 & Santa Rosa artichoke & 1911 \\
\hline Paradox walnut & 1893 & Santa Rosa dahlia & & Hybrid sunflowers & 1914 \\
\hline Royal walnut & 1893 & Burbank Crimson California poppy & 1904 & New Burbank Early tomato & 1915 \\
\hline Van Deman quince & 1893 & Santa Rosa Shirley poppies & 1904 & Sunrise daylily & 1917 \\
\hline Lemon Giant calla lily & 1893 & Rutland plumcot & 1905 & Elephant garlic & 1919 \\
\hline Iceberg white blackberry & 1894 & Burbank's Giant Hybrid amaryllis & 1906 & Robusta strawberry & 1920 \\
\hline Wickson plum & 1894 & Santa Rosa plum & 1906 & Sebastopol thornless blackberry & 1920 \\
\hline Tarrytown canna lily & 1895 & Spineless cacti & 1907 & Molten Fire amaranthus & 1922 \\
\hline Burbank rose & 1899 & Burbank Admiral pea & 1908 & Tower of Gold knophoria (poker plant) & 1923 \\
\hline New gladiolus hybrids & 1899 & America Admiral pea & 1908 & Burbank Giant Dahlia zinnia & 1935 \\
\hline White agapanthus & 1899 & Sunberry (Wonderberry) & 1909 & Gold nectarine & $1927^{y}$ \\
\hline Crimson Winter rhubarb & 1900 & America Evening primrose & 1910 & July Elberta peach & $1932^{y}$ \\
\hline
\end{tabular}

${ }^{\mathrm{z}}$ Adapted from Smith (2009)

yPosthumous. 


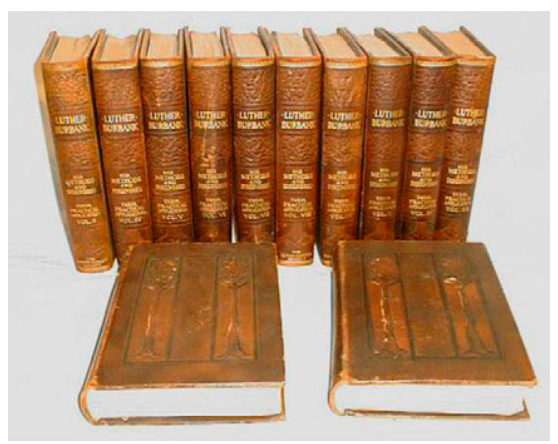

Fig. 6. The 12-volume set of Luther Burbank: His Methods and Discoveries, 1914-15.

A famous photograph (Fig. 7) taken in Santa Rosa on 22 Oct. 1915 with Thomas Edison, Luther Burbank, and Henry Ford in an informal pose on the steps of his garden is a testament to his new status. Ford and Edison had taken a pilgrimage after the opening of the Panama-Pacific Exposition in San Francisco to visit the "wizard of Santa Rosa." The three men obviously enjoyed each other's company with their hats in hand epitomized the American dream: three country boys, self-made men, who achieved concrete results based on their abilities. For Luther it was a vindication of his life's work that announced his membership in the trinity of American inventive heroes. In popular imagination, Burbank was to enter the panoply of great inventors along with Alexander Graham Bell, the Wright Brothers, Thomas A. Edison, and Henry Ford. A collection of Burbank memorabilia would be collected by Ford for his Dearborn Museum of Americana.

Epilogue. Who was Luther Burbank? Perhaps the best metaphor is Frida Kahlo's mystical, surrealist portrait of Burbank dressed in a dark suit and holding a philodendron emanating from a hollow stump with roots feeding on a corpse (Fig. 8). In the background are two trees laden with fruit in a desiccated landscape of California. Indeed, Burbank was a plant mystic who created new plants with little more than his imagination, his pollinating abilities, and his skill for selection. His guiding light was not Mendel but Darwin (whose evolutionary concepts were not reconciled with Mendelian genetics

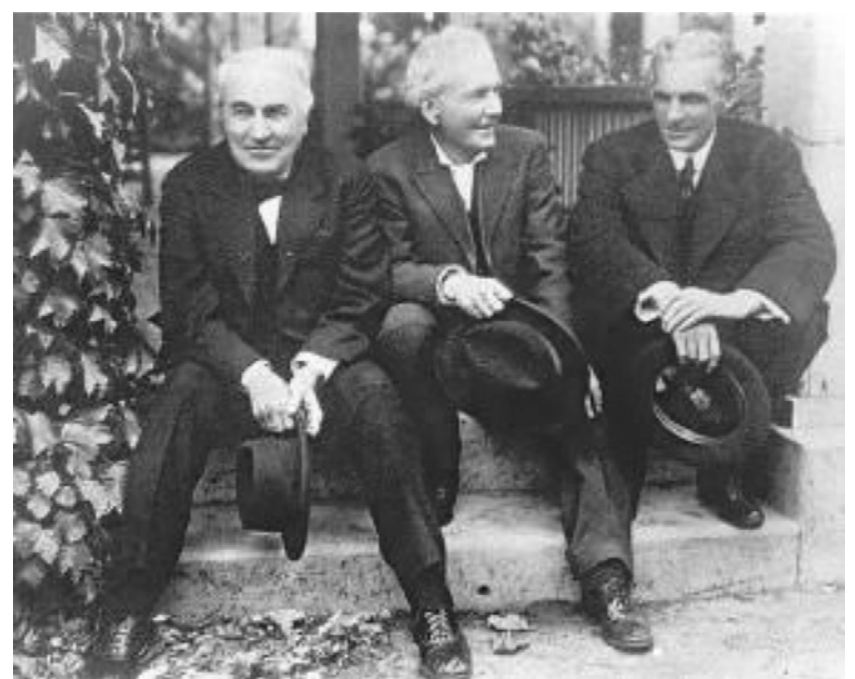

Fig. 7. Three famous Americans: Thomas A. Edison, Luther Burbank, and Henry Ford at Santa Rosa, 1915.

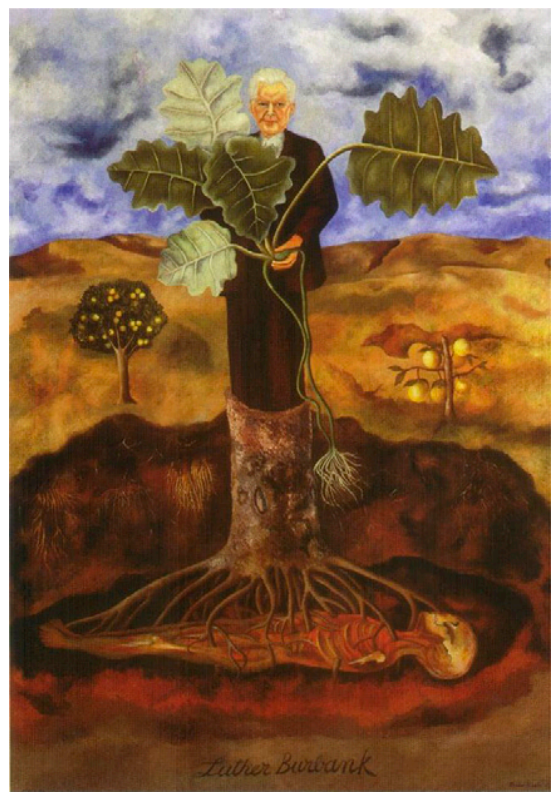

Fig. 8. Portrait of Luther Burbank as the plant breeding mystic by Frida Kahlo, 1931.

until the work of R.A. Fisher in 1918) who led him to the belief that plants could be altered to better serve the needs of humans. The proof of the pudding is in the eating, and the proof of Burbank's genius as a horticulturist and plant breeder was his creations that still enrich our lives.

\section{Literature Cited}

Crow, J.F. 2001. Plant breeding giants: Burbank, the artist; Vavilov, the scientist. Genetics 158:1391-1395

Dreyer, P. 1993. A gardener touched with genius: The life of Luther Burbank. 2nd Ed. Luther Burbank Home and Gardens, Santa Rosa, CA.

Howard, W. 1945. Luther Burbank's plant contributions. Bul. 691. Chronica Botanic, University of California College of Agriculture, Agricultural Experiment Station, Berkeley, CA.

Howard, W. 1945-46. Luther Burbank, a victim of hero worship. Chron. Bot. 9(5/6)

Jones, D.F. 1937. The life and work of Luther Burbank. Spragg Mem. Lectures, Plant Breeding. Michigan State College, East Lansing, MI. p. 37-76.

Smith, J.S. 2009. The garden of invention: Luther Burbank and the business of breeding plants. Penguin Books, London. UK.

Williams, H.S. (ed.). 1915. Burbank, his life and works. Heart's International Library Co., New York, NY.

Williams, H.S., R.J. Whitson, and J. Whitson (eds.). 1914. Luther Burbank, his methods and discoveries. Luther Burbank Press, New York, NY. 